\title{
Determinants of Loan Repayment of Government Funding to Vulnerable Groups; A Case of Biashara Fund in Kiambu County, Kenya
}

Mbugua Keziah Njoki Dr. George Kosimbei

\author{
Department of Public Policy and Administration, Kenyatta University, Kenya
}

\section{ABSTRACT}

In an attempt to alleviate poverty and empower the vulnerable population, many nongovernmental organizations and government line agencies have provided revolving funds to its citizens. The County Government of Kiambu introduced Biashara Fund to empower its youth. The major challenge has been identifying the most deserving beneficiary and minimizing the risk of loan non-repayment. Such, has however not been possible as at times, the rate of defaulters has been reported to be substantially high, leading to writing off such debts at the expense of the revolving funds. The role of the government in providing start-up funds and ensuring sustainability is crucial. Ideally when such funds are borrowed, it is expected that they are repaid in order to empower another beneficiary thus creating a revolving fund and ensuring sustainability of the fund. However, this is often not the case as change of the government of the day at times leads to higher default rate of such funds. This study focused on determinants affecting loan repayment of government funding to venerable groups, a case study of Biashara Fund in Kiambu County, Kenya. The study specifically evaluated the influence of amount of credit borrowed, legislation put in place on loan repayment, borrowing process set and group leadership on loan repayment of government funding to venerable groups accessing Biashara Fund in Kiambu County. Descriptive survey was adopted for this study. The study targeted youth, women and persons with disability with emphasis on 60 groups and 865 individuals drawn across the 10 sub-counties in Kiambu County. The target category had advanced loans by the Biashara Fund from 2014 to 2017. A sample of 274 participants was used and was selected using stratified and simple random sampling. The study used a questionnaire as the sole primary data collection instrument. Data was analyzed using the Statistical Package for Social Sciences where both descriptive and inferential statistics were employ yed. A univariate analysis was done to get standard deviation, means frequency tables, histogram pie chart, graphs and percentages. Further inferential statistics were applied using regression analysis. The study established a relationship between group leadership and loan repayment of government funding by venerable groups accessing Biashara Fund in Kiambu County. The study findings show that there is a significant negative relationship between the amount of credit borrowed and loan repayment of government funding by venerable groups accessing Biashara Fund in Kiambu County. The study concludes that there is a relationship between loan size and capacity to repay. The study also concludes that most of the youth, women and persons with disability were partially conversant with the Biashara loan rules. Policy makers need to come up with viable interventions to stimulate and create an enabling economic environment for innovation and business competitiveness, hence inducing performance of youth, women and disabled business projects. The youth, women and disabled problem thus requires properly planned well-structured and broad based programs. The study recommends that adequate liquidity should be ensured as depositors and borrowers should be able to access funds without subjecting the institutions to solvency and attainment of acceptable rates of return. Research and academicians with an interest in entrepreneurship and startup funding as they will understand the issues raised for future research. 
Key Words: Loan Repayment, Government Funding, Vulnerable Groups, Credit Borrowed Loan Legislation, Borrowing Process, Group Leadership, Biashara Fund In Kiambu County, Kenya

DOI: $10.35942 /$ ijcab.v3iVI.80

\section{Cite this Article:}

Mbugua, K., \& Kosimbei, G. (2019). Determinants of Loan Repayment of Government Funding to Vulnerable Groups; A Case of Biashara Fund in Kiambu County, Kenya. International Journal of Current Aspects, 3(VI), 83-100. https://doi.org/10.35942/ijcab.v3iVI.80

\section{Introduction}

Governments have continued to focus on enhancing access to funds among vulnerable groups to drive small and medium sized businesses to promote economic growth (UNDP, 2014). The importance of using other forms of credit and financial services which is easily accessible and friendlier for small businesses growth among vulnerable groups is quite significant. Thus, new, innovative and pro-poor models for financing youth, women and persons with disability upcoming businesses have been developed in Kenya (Oduol, 2013). Globally, most formal financial sectors like banks have been unwilling to offer credit to start-ups, medium and small enterprises due to lack of collateral or security to support such loans, thus resulting to high transaction costs, lower education levels and high cost of monitoring (UNOPS, 2012). Such upcoming businesses are often categorized as high risk due to low revenue or collapse within the first year of establishment, hence financial institutions shy away from lending these groups of people. Microfinance programs provide small scale financial services to low income individuals. Loans are designed to foster sustainable economic empowerment and capacity building for people in developing economies in order to increase capacity and their profits, thus better financial performance. However, microfinance and microcredit programs have been under critism recently due to uncontrolled lending practices by unmonitored and irresponsible organizations. Access to microcredit is a major constraint for small scale entrepreneurs sector and a complicated challenge. For this reason, governments have over the years shown interest and efforts have been made to improve access to funds for low income earners and consequently expanded policies for previously marginalized groups (WBG, 2016).

The Kenya National Bureau of Statistics (2017), report stipulates that out of $60 \%$ youth population, $75 \%$ are either jobless or in the non-formal employment sector. These figures, are exclusive of women and persons with disability considered as vulnerable groups and are above the age of 35 years. The government therefore saw the need to have a revolving fund aimed at empowering the youth as well as venerable groups thus the launch of Uwezo Fund. Uwezo Fund is a flagship programme for Vision 2030 aimed at enabling women, youth and persons with disability access finances to promote enterprises at the Constituency level, thereby enhancing economic growth towards the realization of the same and Millenium Development Goals Number 1 (Eradicate extreme poverty and hunger) and 3 (promote gender equality and empower women) (KIPPRA, 2016). This Fund was launched in September 2013 and enacted through a Legal Notice No. 21 of the Public Finance Management Act, 2014 and published in February 2014 (Mutuku, 2014). The Fund seeks to expand access to finances and promote women, youth and persons with disability led enterprises at the Constituency level. It also provides mentorship opportunities to enable the beneficiaries take advantage of the $30 \%$ government procurement preference through its capacity building program. It is among other funds like Youth Enterprise 
Fund and Women Enterprise Fund an avenue for incubating enterprises, catalyzing innovation, promoting industry, creating employment and growing the economy (Wanjohi, 2013).

Since 2013, the Kenyan government has an account of Kshs 5.2 billion. Out of this figure Kshs 545.3 million has been given to 12,407 group projects country wide and the remaining Kshs 54.2 million has been distributed to 2111 individual youth enterprises at the constituency level (World Bank Report 2015). Furthermore, the Youth Enterprise Development Fund booklet (2016), points out that the fund facilitates the marketing of products and services of youth, youth, women and persons with disability enterprises both in domestic and the international markets and provides more business development services to young entrepreneurs and facilitates the employment of youth in the international labor market. However the repayment of loans has proved more difficult among the beneficiaries of this funds. Both the National and the county government have put effort to reduce the default rate without any success. The rate of defaulters by youth, women and persons with disability who have benefited from government revolving funds is alarming and the bad debtors will negatively affect the purpose of such funds if left unchecked as these are public funds which need to be safeguarded (KIPPRA, 2016).

Kiambu County has adopted a similar revolving fund from the year 2013 dubbed as Kiambu County Youth, Women and Persons with Disability Enterprise Development Fund, popularly known as Biashara Fund that set aside 300 million shillings in the financial year 2014/15 with an additional allocation of 100 million shillings every year (RoK, 2016). The loan is given at a very low interest rate and is supposed to be serviced on monthly basis for a stipulated time but not more than five years. Loan repayment is a necessary ingredient for sustaining such government funding. However the default rate has been over $60 \%$ hence influencing the aimed purpose of the fund at the county level. This makes the county government to shy away from loaning other emerging apart from those with a history of not defaulting. This thus may create a gap if a government chooses not to provide monies towards a revolving fund as this will mean less affordable financing or capital for small and medium sized enterprises funding. The far reaching effects are less opportunities for the creation of self - employment and thus a weaker economy as those in the age bracket that are able to work will remain unemployed. There is therefore need to investigate the This study focuses on determinants affecting loan repayment of government funding to venerable groups, a case study of Biashara Fund in Kiambu County, Kenya.

\section{Statement of the Problem}

The default rate of Biashara Fund currently stands at 68\% (Kiambu Biashara Fund Office). This figure in comparison to $60 \%$ default rate nationally an indication that Kiambu has a high default rate. The factors that have led to the high default have been cited by KNBS and SID (2017) report as lack of business empowerment training programs, high number of groups sourcing for funds thus resulting to minimize funding resulting to poor project planning, lack of project management skills, poor legislation and process of recovering the loans and corruption in favor of certain political leadership interest. There is therefore need to investigate the determinants that contribute to repayment and non- repayment of public funds. Studies previously conducted have found that determinant of loan repayments are varied (Chulkov and Desai, 2014; Otuki, 2014). There is need to focus more on government funding institutions to enhance their effectiveness in the provision of revolving funds to vulnerable groups. However, proper policy, legal and regulatory frameworks have not been put in place to promote viable and sustainable revolving funds. Besides there is little empirical evidence available on determinants affecting loan repayment of government funding to venerable groups accessing Biashara Fund in Kiambu 
County. This study will examine the determinants affecting loan repayment of government funding to venerable groups accessing Biashara Fund in Kiambu County, a County Government initiative in order to fill this gap.

\section{Objectives of the Study}

The Objectives of this study were to:

i. To evaluate the determinants of amount of credit borrowed on loan repayment of government funding to venerable groups accessing Biashara Fund in Kiambu County.

ii. To assess the effectiveness of legislation put in place on loan repayment of government funding to venerable groups accessing Biashara Fund in Kiambu County.

iii. To determine the determinants of borrowing process set on loan repayment of government funding to venerable groups accessing Biashara Fund in Kiambu County.

iv. To examine the determinants of group leadership on loan repayment of government funding to venerable groups accessing Biashara Fund in Kiambu County.

\section{Theoretical Framework}

The study will be anchored on Empowerment Theory which is the main theory supported by Group Lending in Theory and Joint Liability Theory as presented below:-

\subsection{Empowerment Theory}

The key theory to guide this study will be empowerment theory by Zimmerman (2013). The theory is best as it demonstrates the need to empower individuals in the society. Zimmerman and Warschausky (2013) focus on the individual level at which financial empowerment occurs. The theoretical extension moves from financial to psychological which comprises of the intrapersonal and behavioral mechanism. Intrapersonal component refers to how people judge themselves and include domain supposed control and self-efficacy motivation to control and perceive proficiency. Interpersonal component relates to critical awareness and an understanding of the resources needed to achieve a desired goal, knowledge of how to acquire those resources and skills for managing resources one has obtained as well decision making, problem solving and leadership skills. Empowering the society through set funds ensure they acquire knowledge and skills to prepare them for the labor market and also they create more businesses which can empower others. The kind of knowledge includes human rights, social justice and selfawareness. Psychological empowerment emphasizes an individual knowledge and skills for effective action as well as the individual's capacity and willingness to handle such an effort (Zimmerman, 2013). Knowledge and skills are relevant in the youth acquisition of some form of employment for financial independence. According to Friedman (2015) empowerment has three dimensions which include processes, values and outcomes that differ across levels of study. They contend that an empowerment approach should always reinforce positive values and assist people to become as independent as possible. Independence of the youth can be achieved through financial support offered to them by the government and through education and training for skills.

Funds are important in ensuring the youth, women and disabled population establish their own enterprises for self- employment. Skills such as entrepreneurial skills would facilitate their success in business management (Hennessy, 2015). Education on the other hand would enable the youth find job in the formal sector. When this special category of citizens engage in productive economic activities they will be financially independent (Woods and Joyce, 2014). 
This theory is relevant to this study by showing that it is vital to empower individuals and groups to become self-reliant and free from external control. Youth, women and persons with disability after gaining a sense of financial independence will not be easily manipulated or influenced by political elites to carry out activities that are likely to disturb peace since they will exercise personal control (Zimmerman, 2013). An empowered person is then expected to exhibit a sense of personal control, critical awareness and a willingness to work with others to achieve a certain goal. Empowered youth, women and persons with disability will also demonstrate an understanding of who they are, exercise self-control through education for self-awareness, and be able to participate in the development of their country through engagement in productive economic activities and decision making on matters that concern them.

\subsection{Group Lending in Theory}

Group lending in theory as proposed by Ludwig von Bertalanffy (1968) is also known as solidarity group theory which is also most often-discussed as solution to information asymmetries in developing countries. In this theory, as postulated by Jassawalla and Sashittal (2015), adverse selection and moral hazards are dealt with by effectively changing the responsibility of enforcement, monitoring, screening and from the lender to youth, women and persons with disabilities. The peer group, who usually consist of a number of individual who come together as a group, borrow a loan together in solidarity. Members are self-selected based on their reputation and relationship with each other. Group liability requires that in case one group member defaults, the fellow group members will be responsible for his/her payment Gebremedhin, Getachew and Amha (2015). Under group liability funds then, youth, women and persons with disabilities groups have an inducement to screen other interested groups so that only the trustworthy individuals are allowed into the programme. This theory is important to this study as the theory portrays group lending as a means of addressing moral hazard by providing incentives for youth, women and persons with disabilities groups to employ peer pressure to ensure that funds are invested properly and effort exerted until the loans are repaid in full. By lowering default, the expected total cost of borrowing for borrowers can be condensed, improving welfare especially for households without collateral.

\subsection{Joint Liability Theory}

This theory is applied to government lending agencies, SACCOs and MFIs (Microfinance) who practice group lending in a bid to minimize the risks of by default and delinquency by the borrowers (Robbin and DeCenzo, 2015). O'Sullivan and Abela (2016) stress that through joint liability the financial institutions have been able to reach to many people such as the unbankable and the poor that does not have collaterals to secure loans. This theory support unconventional lending practiced by the Munusamy, Chelliah and Mun (2015), the Joint liability lending institutions ask borrowers to form groups in which all borrowers are jointly liable to one another. These lenders are also characterized by intensive monitoring of the borrowers and rely heavily on past borrowers to ensure compliance. Capusneanu and Lodhi (2012) puts it that for the lending institutions to experience high loan repayment rates from borrowers there is need to encourage the borrowers to form groups such that the paying members can pressurize the nonpaying, or those on the verge of defaulting to honour their contractual obligations. The foremost bond of allegiance is between the borrowers whereby a case of default is treated as a departure from the set norms and ideals of the group. In this the lending institution is able to follows on its clients and ensures that constant monitoring on their loan repayment behaviour can is achieved 
(Delaney and Huselid, 2016). This thus ensures that there are costs sharing between the borrowers and the lending organization.

\section{Empirical Literature}

A study by Rodrý guez (2011) in Yugoslavia shows that youth funds and other associated funds face the challenge of inconsistency in budgetary allocation from the government which makes it unable to adequately fund the growing number of venerable groups on the enterprise development mandate. Some of the identified challenges include:-high cost of providing business development services, which include mentorship and business coaching to young entrepreneurs due to large number of beneficiaries' involved and increasing demand. The main one being the amount of credit borrowed by beneficiaries leading to high rates of defaulting. According to Pratten and Ryan (2014), those borrowers who apply for bigger loan amount and longer loan repayment period could have a problem in their loan repayment unlike those who get small amount and be improved in order to encourage the borrower to pay back their loan. Failure to pay back their loan is divided into two different issues namely not paying back the loan at all and delayed loan repayment. Kourilsky (2013) noted that the loan interest rate and the amount lent are the main factors affecting repayment of the loans. Using the interest rate that an individual or group is willing to pay by most of the financial institution poses a serious challenge as individual as a device to identified borrower with a high probability of loan repayment. This may be dangerous since high risk-takers are the worst rate payers.

Bapuji and Crossan (2014) assert that, non-supervision of borrowers influences the loan repayment. Cherry (2014) postulates that, the general problem for lack of supervision of a member, affects the loan utilization and makes the members to absent themselves from group meetings. Again, if the loan is not supervised regularly, it encourages misuse of loan and members are not able to pay up their instalments, confidence on each other and the discipline of the group is hampered. Additionally, a lot of work will be created for the staff as they try to follow-up the loan defaulters, the members also lose confidence with the revolving fund institution and conceive wrong ideas of revolving fund borrowing and eventually, the individual group member loses his/her social status. Adeoye and Elegunde (2012) studied on loan repayment of Loan Beneficiaries by the ministry of youth in Southeast States of Nigeria used a multistage sampling technique to select a total of 144 loan beneficiaries who were randomly interviewed. An ordinary least square (OLS) multiple regression analysis was carried out to isolate and examine the determinants of loans. The findings of the study indicated that loan size was significant at $5 \%$ level of significance and was positively related to loan repayment rate. This implies, that the greater the size of the loan, the lower the default. This was true up to a certain point though as there was an optimum amount of loan (or funds) that would be required to break even in projects. Moreover, it is contended that bigger loans make possible larger investments with potentially higher returns. About $75 \%$ of the loan beneficiaries indicated that the sizes of their loans were inadequate, thus supporting this viewpoint. Hoque and James (2011) studied on economic analysis of loan repayment capacity by venerable groups focusing on the disabled in Zimbabwe. The result revealed a strong positive and significant relationship between loan size and capacity to repay. By implication, given that beneficiaries did not have the tendency to divert, if substantial amount was approved as loan, they would use the funds to acquire the basic tools, equipment, and improved technology to enhance their operational and marketing efficiency and make positive returns. In other words, larger loan sizes would enhance the beneficiary access to basic inputs and improve the project management opportunities, which 
would lead to higher productivity, reduced per unit cost and increased income. The investment would be able to pay back itself and consequently support them to repay the borrowed fund within the specified period. Similar positive influence of loan size on loan repayment performance had been variously reported in separate studies (Bell, 2012; Khalif, 2016; Nokes, 2014).

Charles (2012) posits that legislations by the funders of youth, women and people with disability are a key hindrance to them repaying their loans. The study which was conducted in Pakistan recommends that legislations should be accompanied with a combination of skills training (usually non formal education), mentoring and guidance combined with helping beneficiaries gain access to financial capital. Skills training programs should provide beneficiaries with opportunities to master core literacy and numeracy skills, vocational as well as life skills. Funds for this category of beneficiaries should focus mainly on knowledge and experience gaining rather than loan repayment process. Wabwire (2015) posits that favorable policies are very important for policy makers, as an attempt to understand categories of youth entrepreneurial behavior characteristics enables the policy makers to come up with viable interventions to stimulate and create an enabling economic environment for innovation and business competitiveness, hence inducing performance of youth, women and disabled business projects. The youth, women and disabled problem thus requires properly planned well-structured and broad based programs. So far the government seems to be tinkering at the superficial level without a long term, comprehensive plan. Accelerating economic growth is central to creating employment opportunities for youth, women and disabled as well as providing market drives education and training and life skills.

A study by O'Sullivan and Abela (2016) in Bosnia show that the important factors that contribute to loan repayment performance are the design features of the loan. They categorize the design features into three categories namely access methods, screening methods and incentive to repay. Shields and Rangarjan (2013) stated that the characteristics of legislation of youth funds and other related funds products should include: small amounts of loans and savings, short loan terms, payment schedules featuring frequent installments, easy access to the intermediary, simple application forms which are easy to complete, availability of repeat loans in higher amounts for clients who pay on time. Friedman (2015), suggests that lenders should look at the borrowers past record and economic prospects to determine whether the borrower is likely to repay or not. Besides characters of borrowers, collateral requirements, capacity and ability to repay and condition of the market should be considered before giving loans to the borrowers. The factors affecting loan repayment performance of MFIs can be divided into four factors namely individual/borrowers factors, firm factors, loan factors and institutional/lender factors (Robbin and DeCenzo, 2015).

Sekaran and Bougie (2011) highlights that the main reasons for the existence loan faults among the borrowers is that the financial institution are not keen on their terms of loan repayment since most borrowers may take advantage of the loophole and hence they are unwilling to repay and also the financial institution's staffs are not responsible to shareholders a and if loans are given without the proper evaluation of the borrowers business. The loan repayment mechanism and infrastructures put in place in some part of the country especially in rural areas poses serious challenges to disbursement of loan and inability to repay due to lack of financial intermediaries and loan repayment avenues disadvantages the youth in those areas (Suddaby, 2011). 
According to Youker (2011) those participating in legislating in empowerment program management forums should understand that; each member of the team understands how His or Her individual piece of the project fits to the big picture. More ideas are generated; better decisions are made; participation creates ownership, which strengthens commitment and accountability, team morale is usually higher, there is less rework and individual and team performance is used. According to Wheelen and Hunger (2016) participatory approach provides better youth, women and disabled empowerment program results. Fletcher (2011) further indicated that planning the project consists of determining which tasks needs to be completed to achieve youth, women and disabled empowerment program objective and allows the youth, women and disabled empowerment program manager to draw the empowerment plan.

Raynor and Ahmed (2013) undertook a study in Ethiopa to analyze and identify the major factors that determine loan repayment performance of the youth, women and disabled and to identify the major challenges of the MFI's in the Wolaita and Dawuro area. Repayment period was found to be a significant determinant of loan repayment performance of borrowers. Suitability of loan repayment period for borrowers was found to significantly increase the probability of repaying loan. Therefore, the institution has to give enough time to clients so that they will be able to work with the loans they have borrowed and arrange the time to collect loan that will be suitable for them to sell their business output. Greenwood and Suddaby (2016) studied Essays on Group Lending: Evidence from Jordan, in this study data from a self-designed survey of 160 borrowing groups of the Micro fund for Women in Jordan was used to test the effect of screening, peer monitoring, group pressure, and social ties on borrowing groups' behavior. If the primary penalty for default or delinquency is denial of future loans, clients will presumably be more willing to risk bad behavior as their outside options expand. In such cases, factors such as loan repayment schedule may have a marginal impact on delinquency and default. A study by Hodgetts and Luthans (2013) shows that in an attempt to address the theme on youth, women and disabled unemployment and empowerment, the Government of Tanzania has come up with various policy documents such as Poverty Reduction Strategy Paper which extensively elaborates on youth, women and disabled empowerment legislated strategies through training on entrepreneurship, vocational training as well as career guidance service development. This has boosted the loan repayment to a $12 \%$ increase from $43 \%$ in the previous years.

Kerr and Slocum (2015) on their study on the determinants of loan repayment performance of youth and disabled in Ghana where a multiple regression was employed shows that, low level of education, lack of alternative source of income, difficult loan processing procedures are the main causes of high loan default. They also identified the incomes that are generated from projects and the sizes of loan invested are the significant indicators' of loan repayment. Leonard, Scholl and Kowalski (2015) study in Norway shows that easy and proper regulation of revolving fund are expected to lead to quality growth, broaden the funding base from revolving fund institutions eligible to minimize and administer deposits, broaden credit facilities and initiate process of integrating the institutions in the formal financial institutions. The regulation of the government revolving funds enable the government to define procedures for her operations, entrance and exit of firms and groups; and ultimately create an environment for fair competition and efficiency in the sector. The study recommends that adequate liquidity should be ensured as depositors and borrowers should be able to access funds without subjecting the institutions to solvency and attainment of acceptable rates of return. 
Suleiman (2012) carried out a research on factors influencing the loan repayment of youth and women fund in China. The research targeted 52 groups' officials and adopted a descriptive survey design where data was collected from fifty youth groups funded through the development fund. The findings revealed that if borrowing process if they become bureaucratic find clients in a full of unpredictable crises, then such funds results towards personal use rather than the intended project. Muya and Wesonga (2012) reported that most of the default arose from delayed receipt of borrowed funds as a resulting to poor management procedures, loan diversion and unwillingness to repay loans. Therefore, lenders must devise various institutional mechanisms aimed at reducing the loan diversion.

According to Tay and Diener (2011), inadequate and prolonged borrowing process, awareness and information technology and appropriate education are some of the discouraging factors for business ideas. Others are cultural taboos, legal systems that fail to protect innovations and competitive business enterprises as well as small weak markets and excessive regulations that frustrate the implementation of business ideas into reality. The findings show that beneficiaries face a lot of challenges in accessing finances to inject in their business both as startup, seed capital and finance expansion of the businesses. This is because of many factors which make their businesses less attractive in terms of lending. Due to the lack of self-sustaining resources, the absence of a substantive credit history, sufficient collateral or guarantees to secure loans or lines of credit, young people are often seen as particularly risky investments and therefore face difficulties in accessing finance. Operations of many financial institutions are tailored to offer credit to formally registered businesses which meet criteria such as proper maintenance of books of accounts and verifiable asset base.

Purcell and Kinnie (2016) isolated borrowing process, among two other variables, that are important and have positive relationship with loan repayment in Imo State. Sollund (2016) in his study on the impact of borrowing process, agreed with this view point. Another perspective to this variable was the loan process whether borrowing or refunding the loan, the higher is the borrower's cost of delaying payment. A larger loan is more difficult to repay if allowed to accumulate especially where there are compounding interest and sanctions. This view puts pressure on the borrower to reduce late payments and serious default. In the sample, recorded incremental penalty rate of interest for delay payment was minimal.

Cropanzano and Rupp (2012) observed that; unlike formal finance, informal lenders often attach more importance to loan screening than to monitoring the use of credit. The screening process usually involves the lender's assessment of the prospective borrower through non-credit transactions over a number of seasons, asking for references or personal sureties, asking questions from other people from the lender's village, and visiting the applicant's farm or business. In group lending, screening practices include group observation of individual habits, personal knowledge by individual money-lenders and recommendations by members of the group. In this lending programme, members are made jointly liable for the loans given and the joint liability plus the threat of losing access to future loans motivates members to perform the function of screening of loan applicants, monitoring borrowers and enforcing loan repayment.

A study by Kourilsky (2013) in South Africa shows that youth, women and disabled persons often have difficulties in meeting strict credit scoring criteria as the revolving funds often deal arbitrarily with terms and conditions. There is a lack of binding rules and clear general terms ensuring the transparency of rating procedures and credit scoring systems for youth, women and disabled persons. They are easily put off by the documentation procedures and information 
required by many lenders of credit. Particularly funds requiring less or no collaterals but that charge very high interest rates and fees often have more complex documentation procedures. The disadvantaged groups are often not aware of all available types of finance, funding forms and special support programmes. They often do not understand the concept, the benefits, the possibilities and the drawbacks of the numerous forms of debt and equity financing.

Leadership has been defined as the process of directing or influencing the behaviour of another person or persons towards the accomplishment of some objective. According to Hussain (2015) youth should be seen as experts who are very much aware of what occurs among peers within their communities. Service to the community can move young people beyond their idealistic worlds, thus allowing them to be empathetic to the needs of others. As a result, there is a sense of urgency to embrace the concept of being a leader. While many youth programs should be commended for the support they provide, several struggle with capitalizing on the intrinsic leadership abilities possessed by group leaders. There is often a focus on building skills instead of giving an opportunity to assess how much their leadership abilities have progressed within a given period of time. Their perspective on what young people need is invaluable and should be considered by those youth, women and persons with disability development specialists who have the task of planning programs. Accordingly Kusters et al., (2016) posits that most of the youth participants are given opportunities to practice and refine those skills while building confidence and stronger positive relationships with peers.

Delaney and Huselid (2016) argued that for the lenders to ensure that there is no default on the loan repayment they have advanced to the borrowers they must device structure and mechanism to monitoring borrowers' actions though the use of innovative mechanisms such as regularly scheduled repayments which may indirectly enhances the way lenders get an informed decisions thus ensuring that moral hazard are prevented. Jassawalla and Sashittal (2015), on his study assessed the factors affecting the loan repayment performance of group lending in Tunisia. The results reveal that internal rule of conduct in the group, the way the business is managed, the knowledge of the other members of the group before formation, the peer pressure within the group, the self-selection, the sex, the education level of the group members. However, the homogeneity and the marital status are among the main factors negatively impact on the loan repayment performance of groups. Woods and Joyce (2014), study factors that influence loan repayment performance in microcredit institutions (MFIs) in Tanzania. Their findings revealed that experience, training time and sanctions within the group have significant effects and thus the rate of default on loan repayment among group clients of MFIs is low, but transaction costs and the size of the group had negatively and significant effects on loan repayment performance.

However, Ober (2012) found that the number of years of experience with credit has significantly positive influence on loan repayment. In a study that investigated the borrower's socio-economic determinants of loan repayments in microcredit programmes that applied the group lending in the US, Mnkandla and Marnewick (2014) found that repayment increased with the level of education. On the other hand, the study found that the level of household income, business type and borrower's experience were not significant predictors of loan repayment. Munusamy et al., (2015) argued that group lending by the financial institutions has improved loan repayment performance by the borrowers as oppose to individual lending. He further explains that the support and guidance within the group provides a strong incentive for each individual to operate effectively due to one's personal reputation within the group. Furthermore, since groups generally are formed by members from the same village or community which have a common 
goal and objective thus loan can be repaid in time as this may affect the credibility and accountability within the community at large. However, this social effect can favour the outcomes for the microfinance institutions, some researchers believe that it can lead to an unhealthy social environment within the community at large. Proper utilization of the social capital and the local information within the group reduces the chances of defaulting.

Capusneanu and Lodhi (2012), study factors influencing loan repayment performance by group borrowers in Bungoma County. They found that group meetings with MFIs prior to loan disbursement enhances discipline and order among the members. Proximity of lenders to borrowers is not significant since MFIs have devices other venues such as electronic money transfer and mobile services to minimize travelling challenges among the group. They also found that MFIs schedule meetings with the groups to offer basic training on financial 16 matters before loan disbursement. They also identify politics within the group poses a high risk of defaults. Hatcher (2013) on his research on the determinants of loan repayments in microcredit in group lending approach. They concentrated on the borrower's socio economic factors instead of the elements of group lending for their influence on loan repayment behavior. The results show that a higher educational level is significant and reduces the chances of loan default while female borrowers, level of income, the type of business and the borrowers experience had no significant effects on the loan repayment.

\section{Conceptual Framework}

The independent variables according to the conceptual framework as shown in figure 2.1 will tend to stand in the way in loan repayment of government funding. In other words the loan repayment of the revolved funds like Biashara Fund will be enhanced and improved when these factors are in low percentages. A positive index on the variables will escalate loan repayment of government funding. The more effective the following factors are enhanced which are credit borrowed, loans legislation, borrowing process and group leadership the more loan repayment will be effective by the youth, women and persons with disabilities groups. The effectiveness of loan repayment of government funding will be measured in terms of number of repays on time, delays (delinquent) and default rate. 


\section{Amount of credit borrowed}

- Loan applied/ awarded

- Grace period

- Loan interest

- Flexibility of repayment

\section{Loans legislation}

- Amount of money disbursed

- Group's funds requirement

- Government budget allocation

\section{Borrowing process}

- Follow-up mechanisms

- Processing time

- Information on borrowing

\section{Group leadership}

- Leadership skills

- Level of education

- Level of experience

- Group size

Independent variables

\section{Loan repayment}

- Government funding

- Repays on time

- Delays (delinquent)

- Default

\section{Figure 1: Conceptual framework}

\section{Dependent Variable}

Source: Researcher (2018)

\section{Research Methodology}

Descriptive survey was adopted for this study. Kiambu County covers an area of about 2,543.5 $\mathrm{km}^{2}$. It borders the Counties of Nairobi and Kajiado to the South, Machakos to the East, Murang'a to the North and North East, Nyandarua to the North West, and Nakuru to the West 
(Ministry of Devolution and Planning, 2013). Kiambu County is divided into ten (10) subcounties namely: Gatundu North, Gatundu South, Ruiru, Thika East, Thika West, Githunguri, Kiambu, Limuru, Kikuyu and Lari. Lari sub-county is the largest in size while Thika East is the smallest. The sub-counties are further subdivided into 29 divisions, 95 locations and 236 sublocations. The county has 12 parliamentary constituencies: Gatundu South, Gatundu North, Juja, Ruiru, Thika Town, Kiambu, Kabete, Githunguri, Limuru, Kikuyu, Kiambaa and Lari. Kiambu town is the county headquarters. According to the Kenya Population and Housing Census (KPHC) of 2009, the county's population was 1,623,282. Population refers to the entire group of people or things of interest that the researcher wishes to investigate (Mugenda and Mugenda, 2003). The study targeted youth, women and persons with disability with emphasis on 60 groups and 865 individuals drawn across the 10sub-counties in Kiambu County. The target category had been advanced loans by the Biashara Fund from 2014 to 2017. Accordingly an optimum sample is the one that fulfills the requirements of efficiency, representativeness, reliability and flexibility.

To get a representative sample, Nachmias and Nachmias's (2008) formula was adopted. A 95\% confidence level and $\mathrm{P}=0.05$ was chosen in view of social science nature of the study. The researcher used stratified and simple random sampling to sample out the 274 participants. The choice for this sampling techniques is preferred as it gives each item in the population an equal probability of being selected (Saunders, Lewis and Thornhill, 2007). The study used a questionnaire as the sole primary data collection instrument. The questionnaire contained both open and closed ended questions. Closed ended questions only allowed specific types of responses such as the five likert scale questions while open ended questions enabled respondents to give detailed qualitative responses (Mugenda and Mugenda, 2003). Structured questions were used in an effort to conserve time and to facilitate an easier analysis as they were in immediate usable form. The unstructured questions were used so as to encourage the respondents to give indepth and subjective response without feeling held back in revealing of any information. Data was analyzed using the Statistical Package for Social Sciences (SPSS version 22). All the questionnaires received were referenced and items in the questionnaire coded to facilitate data entry. After data cleaning which entailed checking for errors in entry, descriptive statistics and frequencies were obtained for all variables and information presented in form of frequency tables and graphs.

Both descriptive and inferential statistics were employed. Questions used to collect qualitative data were aligned to the research objectives. The responses were summarized into most occurring in categories according to research objectives. These qualitative findings were integrated with the quantitative findings in discussions. Variable aggregation to come up with indices for different variables was undertaken. A univariate analysis was done to get standard deviation, means frequency tables, histogram pie chart, graphs and percentages.

Inferential statistics provide the basic features of data collected on the variable and provide the impetus for further analysis on the data (Sekaran and Bougie, 2011). Regression analysis was adopted.

\section{Data Analysis Results}

To estimate the relationship between the study variables, the researcher conducted a multiple regression analysis whose results are as shown in Table 1. 
International Journal of Current Aspects, Volume 3, Issue VI, 2019, PP 83-100, ISSN 2616-6976

IJCAB

Table 2: Regression Analysis Results

\begin{tabular}{lccccc} 
Model & \multicolumn{2}{c}{$\begin{array}{c}\text { Unstandardized } \\
\text { Coefficients }\end{array}$} & $\begin{array}{c}\text { Standardized } \\
\text { Coefficients }\end{array}$ & t & Sig. \\
\cline { 2 - 6 } & $\mathbf{B}$ & $\begin{array}{c}\text { Std. } \\
\text { Error }\end{array}$ & Beta & B & \\
\hline (Constant) & 2.921 & .406 & & 7.188 & .000 \\
Amount of credit borrowed & -0.633 & -0.109 & -.136 & 5.807 & .000 \\
Loans legislation & 0.407 & 0.135 & .117 & 3.015 & .003 \\
Borrowing process & 0.388 & 0.118 & .140 & 3.288 & .001 \\
Group leadership & 0.158 & .056 & .196 & 2.803 & .006 \\
\hline
\end{tabular}

The study findings show that there is a significant negative relationship between the amount of credit borrowed and loan repayment of government funding by venerable groups accessing Biashara Fund in Kiambu County $(\beta=-0.633$, sig. value $=0.000)$. The findings indicate that a unit increase in the amount of credit borrowed would lead to a decrease in loan repayment of government funding by venerable groups accessing Biashara Fund in Kiambu County by 0.633 units. This implied that as the amount of credit borrowed increased, there was increased risk of defaulting on loan repayment of government funding by the venerable groups accessing Biashara Fund in Kiambu County. The study findings show that there is a significant positive relationship between loans legislation and loan repayment of government funding by venerable groups accessing Biashara Fund in Kiambu County $(\beta=0.407$, sig. value $=0.003)$. The findings indicate that a unit increase in loans legislation would lead to an increase in loan repayment of government funding by venerable groups accessing Biashara Fund in Kiambu County by 0.407 units. This implied that better loans legislation was positively related to loan repayment of government funding by venerable groups accessing Biashara Fund in Kiambu County.

The study findings show that there is a significant positive relationship between borrowing process and loan repayment of government funding by venerable groups accessing Biashara Fund in Kiambu County $(\beta=0.388$, sig. value $=0.001)$. The findings indicate that a unit increase in the borrowing process requirements would lead to an increase in loan repayment of government funding by venerable groups accessing Biashara Fund in Kiambu County by 0.388 units. This implied that a more stringent borrowing process was positively related to loan repayment of government funding by venerable groups accessing Biashara Fund in Kiambu County. The study findings show that there is a significant positive relationship between group leadership and loan repayment of government funding by venerable groups accessing Biashara Fund in Kiambu County $(\beta=0.158$, sig. value $=0.006)$. The findings indicate that a unit increase in group leadership would lead to an increase in loan repayment of government funding by venerable groups accessing Biashara Fund in Kiambu County by 0.158 units. This implied that better group leadership was positively related to loan repayment of government funding by venerable groups accessing Biashara Fund in Kiambu County.

\section{Conclusions}

The study concludes that there is a relationship between loan size and capacity to repay. This is because those borrowers who apply for bigger loan amounts and longer loan repayment period could have a problem in their loan repayment unlike those who get small amount and be 
improved in order to encourage the borrower to pay back their loan. The study also concludes that most of the youth, women and persons with disability were partially conversant with the Biashara loan rules. This thus shows that there is need to consider legislations should be accompanied with a combination of skills training (usually non formal education), mentoring and guidance combined with helping beneficiaries gain access to financial capital. Skills training programs should provide beneficiaries with opportunities to master core literacy and numeracy skills, vocational as well as life skills. Funds for this category of beneficiaries should focus mainly on knowledge and experience gaining rather than loan repayment process.

The study further concludes that the borrowing process of Biashara Fund was very bureaucratic, frustrating and slow. This is need for easy and proper regulation of revolving funds so as to lead to quality growth, broaden the funding base from revolving fund institutions eligible to minimize and administer deposits, broaden credit facilities and initiate process of integrating the institutions in the formal financial institutions. The study finally concludes that leadership factors influenced respondents' loan repayment rate to a great extent. Level of experience in leadership, group size management, level of education of the leaders and leadership skills influenced respondents' loan repayment rate influenced respondents' loan repayment rate to a great extent.

\section{Recommendations}

Policy makers need to come up with viable interventions to stimulate and create an enabling economic environment for innovation and business competitiveness, hence inducing performance of youth, women and disabled business projects. The youth, women and disabled problem thus requires properly planned well-structured and broad based programs. The study recommends that adequate liquidity should be ensured as depositors and borrowers should be able to access funds without subjecting the institutions to solvency and attainment of acceptable rates of return. Lenders should ensure that there is no default on the loan repayment they have advanced to the borrowers, they must device structures and mechanisms to monitor borrowers' actions though the use of innovative mechanisms such as regularly scheduled repayments which may indirectly enhance the way lenders get informed decisions thus ensuring that moral hazards are prevented.

\section{REFERENCES}

Adeoye A. \& Elegunde, A. (2012). "Impacts of external business environment on organizational performance in the food and beverage industry in Nigeria", British Journal of Arts and Social Science, 6, (2). 13-65

Bapuji, H. \& Crossan, M. (2014) From Questions to answers: Reviewing Organizational Learning Research. Management Learning. 35, (4), 397-417.

Bell, P. (2012). Building a Monitoring and Evaluation System for Climate Change Adaptaions Projects. Challenges and Strategies towards Stakeholders Involvement. Indonesia:

Asian Cities Climate Change Resilience Network (ACCCRN).

Bertalanffy, G. (1968). ProPack II: Project Management and Implementation Guidance for CRS Project and Program Managers. Lisbon, Catholic Relief Services.

Biashara Fund data base (2018). Economic Recovery Strategy for Wealth and Employment Creation. Nairobi: Government Printers

Capusneanu S. \& Lodhi, A. (2012). Organizational structure as determinant of organizational performance, uncovering essential facets of organic and mechanistic structure, American Journal of Scientific Research, 55, (7), 48-55. 
Charles, L. (2012). Youth Enterprise Development Fund and growth of Enterprise at Constituency level in Kenya. European journal of economics, finance and administrative sciences, 18, (23), 3-4.

Cherry, J. (2014). Youth Entrepreneurship: Meeting the Key Policy Challenges. Oxford, Oxford University.

Cronbach L. (1951). Coefficient alpha and the internal structure of tests. Psychometrika16 (3) 297-334.

Cropanzano, R. \& Rupp, D. (2012). Organization structure and fairness perceptions: The moderating effects of organizational level. Organizational Behavior \& Human Decision Processes, 89, (3), $881-905$.

Delaney, J. \& Huselid, M. (2016). 'The impact of human resource management practices on performance in for-profit and nonprofit organizations', Academy of Management Journal, 39, (7), 949-969

Fletcher, C. (2011) Performance appraisal and management: the developing research agenda, Journal of Occupational and Organizational Psychology, 74 (4), 473-487.

Friedman, M. (2015). A strategy map for results-based budgeting: Moving from theory to practice. Washington, DC: The Finance Project.170

Gebremedhin, B., Getachew, A. \& Amha, R. (2015). Result-Based Monitoring and Evaluation for Organization Working in Agriculture Development: A Guide for Practitioners. Addis Ababa International Livestock Research Institute.

Greenwood R. \& Suddaby. R. (2016). Institutional Entrepreneurship in Mature Fields: The Big Five Accounting Firms. Academy of Management Journal, 49 (1), 27-48.

Hatcher, J. (2013). Advanced Statistics in Research: Reading, Understanding, and Writing Up Data Analysis Results. Publisher: Shadow Finch Media LLC (January 7, 2013). ISBN-13: 978-0985867003

Hennessy, J. (2015). Reinventing Government: Does Leadership Makes a Difference? Public Administration Review, 58(6), 522-32.

Hodgetts, H. \& Luthans, F. (2013).Culture, Strategy, and Behavior. International Management

New York, McGraw-Hill/Irwin, Fifth Edition.

Hoque, Z. \& James, W. (2011). 'Linking balanced scorecard measure to size and market factors: impact on organizational performance', Journal of Management Accounting Research, $12,(5), 1-17$

Hussain, B. (2015). Strategic Management, Formulation, Implementation and Control. New

York: McGraw-Hill.

Jassawalla, S. \& Sashittal, R. (2015). Corporate culture's impact on a strategic approach to quality, Mid-American Journal of Business, 15 (1), 9-20.

Kerr, J. \& Slocum, J. (2015). Managing corporate culture through reward systems. Academy of Management Executive, 19, (9), 130-138

Khalif, H. (2016). Strategic Management and Business Policy: Concepts and Cases. New York, Unites States of America: Pearson Prentice.

Kothari, C. (2008). Research Methodology; Methods and Techniques. New Delhi: New Age International Publishers.

Kourilsky, S. (2013). Entrepreneurial signaling through education: success factor in innovative start-ups, Journal of Small Business Economics: Springer Netherlands; Vol.29 No. 1-2 pg. $173-190$. 
Kusters, C., Vugt, V., Wigboldus, S. \& Woodhill, B. (2016). Making Evaluations Matter: A Practical Guide for Evaluators. Wageningen: Centre for Development Innovation.

Leonard, H., Scholl, R. \& Kowalski K. (2015). Information Processing Style and Decision Making. Journal of Organizational Behavior, 20, (14), 407-420

Mnkandla, E. \& Marnewick, C. (2014). Project management training: The root cause of project failures? Journal of Contemporary Management 8:76-94.

Mugenda, O. \&Mugenda, A. (2003). Research Methods: Qualitative and Quantitative Approaches, Nairobi ACT Press.

Munusamy, J., Chelliah, S \& Mun, H. (2015). Service quality delivery and its impact on customer satisfaction in the banking sector in Malaysia. International Journal of Innovation, Management and technology, 1 (4), 398 - 404.

Muya J. \& Wesonga, J. (2012). The Impact of Organizational Culture on Performance of Educational Institutions. International Journal of Business and Social Science, 3

211-127

Nachmias, C. \& Nachmias, D. (2008). Research Methods in the Social Sciences, New York, Worth Publishers

Nokes, S. (2014). The Definitive Guide to Project Management, n., London (Financial Times/Prentice Hall).ISBN 978-0-273-71097-4.

O'Sullivan, D. \& Abela, A. (2016). Marketing Performance Measurement ability and Firm Performance. Journal of Marketing, 24 (71), 79-93.

Pratten, C. \& Ryan, P. (2014). The Individualisation of Employment Contracts in Britain, London: Department of Trade and Industry Journal. 54 (11). 34-65.

Purcell, J. \& Kinnie, N. (2016). 'HRM and performance', in P. Boxall, J. Purcell and P. Wright (eds), The Oxford Handbook of Human Resource Management, Oxford: Oxford University Press.

Raynor, A. \& Ahmed, M. (2013). Three rules for making a company truly great, Harvard Business Review, 91(4), 76-85.

Robbin S. \& DeCenzo, D. (2015). Fundamentals of Management: Essential Concepts and Applications, Prentice Hall, Upper Saddle River, NJ.

Rodrý guez, A. (2011). The effects of training on performance in service companies. International Journal of Manpower. 30 (4) 393-407.

Saunders, M., Lewis, P. \& Thornhill, A. (2007). Research Methods for Business Students, Edinburgh: Prentice Hall.

Sekaran, U. \& Bougie, R. (2011). Research Methods for business: A skill building approach, $\left(5^{\text {th }}\right.$ ed). New Delhi: John Wiley \& Sons

Sekaran, U. \& Bougie, R. (2011). Research Methods for Business: A skill Building Approach, (5 $5^{\text {th }}$ ed). New Delhi: John Wiley \& Sons

Shields, P. \& Rangarjan, N. (2013). A Playbook for Research Methods: Integrating Conceptual Frameworks and Project Management, Stillwater, OK: New Forums Press.

Sollund, R. (2016). Mechanistic versus organic organizations' impact on immigrant women's work satisfaction and occupational mobility. Scandinavian Journal of Hospitality \& Tourism, 6(4), 287-307.

Suddaby, R. (2011). Construct clarity in theories of management and organization. Academy of Management Review, 35, (9), 346-357. 
Suleiman, S. (2012). The Approaches to Increase Employees Loyalty: A Review on Employees Turnover Models. Australian Journal of Basic and Applied Sciences, 6 (10), 282-291.

Tay, L. \& Diener, E. (2011). Needs and subjective well-being around the world. Journal of Personality and Social Psychology, 101(2), 354.

Wabwire, P. (2015). Fiscal Decentralization in Kenya: a case of the constituency development fund in Kenya- its effectiveness and sustainability on Education projects. Harvard Business Review, 5(7), 11-25.

Wanjohi, E. (2013). Entrepreneurs and entrepreneurship in Africa: What is known and what needs to be done. Journal of Developmental Entrepreneurship, 7(3), 44-75.

Wheelen, H. \& Hunger, K. (2016). Integrating inside and outside innovators: A sociotechnical systems perspective. $R \& D$ Management, 39 (4), 410-419.

Woods, A. \& Joyce, P. (2014). Owner-managers and the practice of strategic management, International Small Business Journal, 21 (2), 181-96

Youker, R., (2011). Managing international development project: lessons learned. Project Management Journal 30 (2), 6-7.

Zimmerman, D. \& Warschausky, I. (2013). Elitists' individualists and risk-takers: an exploratory analysis of cultural differences between entrepreneurs and non-entrepreneurs, Journal of Business Venturing: 7, (8).115-132.

Zimmerman, H. (2013). The Theory of Empowerment Theory: An Inquiry into profits, Capital, Credit, Interest and the Business Cycle. Cambridge, MA: Harvard University Press.

This is an open-access article published and distributed under the terms and conditions of the $(\mathrm{cc}) \mathrm{EY}$ Creative Commons Attribution 4.0 International License of United States unless otherwise stated. Access, citation and distribution of this article is allowed with full recognition of the authors and the source.

Authors seeking to publish with an International Peer Reviewed Journal should consider https://www.ijcab.org/ by writing to the Editor at editor@ijcab.org. The articles must be quality and meet originality test. 